\title{
SUBSTITUSI TEPUNG BONGGOL PISANG DAN Indigofera sp. SEBAGAI PENGGANTI BEKATUL DALAM RANSUM UNTUK MENINGKATKAN PERFORMA AYAM BROILER
}

\author{
Substitusion Effect of Banana Corm Flour and Indigofera sp. Flour as a \\ Replacement of Rice Bran on Broiler Performance
}

\author{
Munifatul Lathifah Ulfa ${ }^{1)}$, Irfan H. Djunaidi ${ }^{2)}$ \\ ${ }^{1)}$ Mahasiswa Minat Nutrisi dan Makanan Ternak, Fakultas Peternakan, Universitas Brawijaya Jalan Veteran, \\ Ketawanggede, Kec. Lowokwaru, Kota Malang, Jawa Timur 65145 \\ 2) Dosen Minat Nutrisi dan Makanan Ternak, Fakultas Peternakan, Universitas Brawijaya Jalan Veteran, \\ Ketawanggede, Kec. Lowokwaru, Kota Malang, Jawa Timur 65145 \\ Email: munifatululfa@gmail.com
}

\begin{abstract}
ABSTRAK
Penelitian ini bertujuan untuk mengetahui pengaruh tingkat penggunaan campuran tepung bonggol pisang dan Indigofera sp. sebagai pengganti bekatul terhadap performa ayam pedaging. Rancangan penelitian yang digunakan adalah Rancangan Acak Lengkap dengan 5 perlakuan dan 4 ulangan. Perlakuan dilakukan pada umur 15-35 hari (fase finisher). Perlakuan yang diberikan sebagai berikut: $P 0=50 \%$ Jagung $+40 \%$ Konsentrat $+10 \%$ Bekatul, $P 1=50 \%$ Jagung $+40 \%$ Konsentrat $+7,5 \%$ Bekatul $+2,5 \%$ Campuran Tepung bonggol pisang dan Indigofera sp. P2 $=50 \%$ Jagung $+40 \%$ Konsentrat $+5 \%$ Bekatul $+5 \%$ Campuran Tepung bonggol pisang dan Indigofera sp. P3 $=50 \%$ Jagung $+40 \%$ Konsentrat + $2,5 \%$ Bekatul $+7,5 \%$ Campuran Tepung bonggol pisang dan Indigofera sp. $P 4=50 \%$ Jagung $+40 \%$ Konsentrat $+10 \%$ Campuran Tepung bonggol pisang dan Indigofera sp. Variabel yang diamati yaitu konsumsi pakan, pertambahan bobot badan, konversi pakan, indeks performa, dan Income Over Feed Cost (IOFC). Data yang diperoleh dianalisis menggunakan Analysis of Variance (ANOVA) dan dilanjutkan Uji Jarak Berganda Duncan (UJBD). Hasil analisis ragam menunjukkan bahwa perlakuan penggunaan campuran tepung bonggol pisang dan Indigofera sp. sebagai pengganti bekatul memberikan pengaruh sangat nyata $(P<0,01)$ pada konsumsi pakan dan berpengaruh nyata $(P<0,05)$ pada pertambahan bobot badan dan menunjukkan hasil yang tidak berpengaruh nyata pada konversi pakan, indeks perfoma, dan Income Over Feed Cost (IOFC).
\end{abstract}

Kata Kunci: Tepung bonggol pisang, indigofera sp, performa ayam pedaging

How to Cite:

Ulfa, M. L., \& Djunaidi, I. H. (2019). Substitusi Tepung Bonggol Pisang dan indigofera sp. Sebagai Pengganti Bekatul dalam Ransum untuk Meningkatkan Performa Ayam Broiler. Jurnal Nutrisi Ternak Tropis 2 (2) 65-72
*Corresponding author:

Munifatul Lathifah Ulfa

Email: munifatululfa@gmail.com

Fakultas Peternakan, Universitas Brawijaya Jalan Veteran, Ketawanggede, Kec. Lowokwaru, Kota Malang, Jawa Timur 65145 


\section{ABSTRACT}

The aim of this research was to determine effect of level using mixture of banana corm flour and Indigofera sp. flour as as replacement of rice bran on broiler performance. The method used was experiment with 5 treatments and 4 replications. The treatment consisted of $P 0($ corn $50 \%+$ concentrate $40 \%+$ rice bran 10\%), P1 (corn 50\% + concentrate $40 \%+$ rice bran $7.5 \%+$ mixture of banana corm flour and Indigofera sp. flour 2.5\%), P2 (corn 50\% + concentrate $40 \%+$ rice bran 5\% + mixture of banana corm flour and Indigofera sp. flour 5\%), P3 (corn 50\% + concentrate 40\% + rice bran $2.5 \%+$ mixture of banana corm flour and Indigofera sp. flour 7.5\%), P4 (corn 50\% + concentrate 40\% + rmixture of banana corm flour and Indigofera sp. flour 10\%). The variables measured were broiler performance including feed intake, body weight gain, feed conversion ratio, performance index and income over feed cost (IOFC). Data were analyzed using Analysis of Variance (ANOVA) of Completely Randomized Design (CRD), if there were significant effect among the treatment the tested by Duncan's Multiple Range Test (DMRT). The results of this research showed that the treatment didn't give effect to all variables except on feed consumption $(P<0.01)$ and body weight gain $(P<0.05)$ increased with increasing level of using mixture of banana corm flour and Indigofera sp. as a replacement of rice bran on performance broiler. Suggestions can be given based on this research is to do further research with using mixture of banana corm flour and Indigofera sp. flour over $10 \%$.

Keyword: Banana corm flour, broiler performance, Indigofera sp. flour, mixture of banana corm and Indigofera sp. flour

\section{PENDAHULUAN}

Indikator keberhasilan dalam suatu usaha peternakan ditentukan oleh efisiensi pakan. Harga pakan yang mahal semakin membuat biaya pemeliharaan semakin tinggi untuk itu diperlukan efisiensi penggunaan pakan. Efisiensi penggunaan pakan dibutuhkan untuk menekan biaya produksi. Oleh karena itu, diperlukan bahan pakan pengganti yang ekonomis (Muharlien, Achmanu dan Kurniawan, 2010 ; Nuningtyas, 2014).

Beberapa bahan pakan cenderung memiliki harga yang fluktuatif sehingga menyebabkan biaya produksi tidak tetap sebagai akibatnya, besarnya keuntungan tidak dapat diprediksi. Salah satu bahan pakan tersebut adalah bekatul sebagai pakan sumber energi bagi ayam pedaging. Bekatul adalah hasil samping proses dalam proses penggilingan padi sedangkan dedak padi merupakan hasil samping penggilingan beras pecah dari kulit padi . Hasil smping penggilingan padi mendapatkan sebanyak 89\% dedak dan b 2-3\% bekatul (Damayanthi dan Listyorini, 2006). Penggunaan bekatul sebagai pakan ternak dapat dikombinasikan dengan bahan pakan lain. Pemberian bekatul dalam pakan ternak unggas dibatasi maksimal 10\% karena tingginya kandungan serat dalam bekatul tidak dapat dicerna oleh ternak, dan kandungan protein yang rendah selain itu terdapat kandungan anti nutrisi berupa phytat yang akan mengganggu jalanya proses pemanfaatan fosfor dan kalsium (Supartini dan Fitasari, 2011).

Harga bekatul yang terkesan fluktuatif berdampak pada biaya produksi. Dengan demikian, diperlukan pakan alternatif sebagai pengganti bekatul. Salah satunya yaitu memanfaatkan limbah perkebunan dan tanaman pakan ternak yang melimpah yakni berupa bonggol pisang dan Indigofera sp.

Bonggol (corm) pisang atau umbi batang pisang merupakan bagian dalam tempat tumbuh tunas dan akar-akar yang menembus kulit luar. Bagian atas umbi batang terdapat titik tumbuh yang menghasilkan daun baru kemudian untuk memperbesar pohon. Bonggol pisang memiliki nilai gizi yang cukup baik, yaitu 
Bahan Kering (BK) 91,56\%, Protein Kasar (PK) 1,72\%, Lemak Kasar (LK) 1,15\%, Serat Kasar (SK) 7,98\%, Karbohidrat 88,16\% (Aswandi, 2016). Berdasarkan kandungan gizi, bonggol pisang memiliki kandungan protein yang rendah, yakni $1,72 \%$. Dengan demikian, perlu ditambahkan leguminosa berupa Indigofera sp. guna mencapai hasil yang optimal.

Bahan pakan sumber protein yang dapat digunakan adalah daun Indigofera sp. Keuntungan dari Indigofera sp. yaitu memiliki produktivitas dan kandungan nutrisi yang tinggi terutama kandungan protein sehingga, dapat dimanfaatkan sebagai bahan pakan ayam pedaging. Menurut Santi (2017), Indigofera mengandung protein kasar 27,89\%, lemak kasar atau ekstrak ether (EE) sebesar 3,70\%, dan serat kasar sebesar 14,96\%.

\section{MATERI DAN METODE}

\section{Lokasi dan Waktu Penelitian}

Penelitian dilaksanakan di peternakan ayam pedaging milik Bapak Syamsul yang beralamatkan di Dusun Bunder, Desa Ampeldento, Kecamatan Karangploso, Kabupaten Malang. Penelitian dilaksanakan selama 35 hari dimulai dari tanggal 19 Maret - 23 April 2019. Analisis kandungan zat makanan bahan pakan dilaksanakan di Laboratorium Pakan Dinas Peternakan dan Perikanan Kabupaten Blitar.

\section{Materi Penelitian}

\section{a. Ayam Pedaging}

Materi penelitian yang digunakan dalam penelitian ini adalah 100 ekor DOC strain Cobb produksi PT. Wonokoyo Jaya Corporindo yang tidak dibedakan jenis kelaminnya (unsexed).

\section{b. Kandang}

Kandang yang digunakan dalam penelitian ini adalah open house dengan alas litter yang diberi sekat membentuk 20 petak dengan alas yang diberi sekam agar dapat menyerap kotoran ayam saat pemeliharaan. Ukuran tiap petak panjang $\times$ lebar $\times$ tinggi, yakni $100 \times 100 \times 70 \mathrm{~cm}$. Setiap petak diisi
5 ekor ayam pedaging. Setiap petak dilengkapi dengan tempat pakan dan tempat minum. Peralatan lain yang digunakan selama penelitian, yaitu lampu 10 watt, alat pensekat, gasolek, alat pembersih kandang, thermohygrometer digital, timbangan digital, bolpoin dan buku.

\section{c. Pakan}

Pakan penelitian yang digunakan selama penelitian yaitu konsentrat ayam pedaging produksi dari PT. Japfa Comfeed Indonesia Tbk, jagung giling, bekatul, dan campuran tepung bonggol pisang dan tepung Indigofera sp. yang dicampur berdasarkan persentase penggunaan masing-masing bahan.

\section{Metode Penelitian}

Metode penelitian yang digunakan adalah percobaan lapang dengan Rancangan Acak Lengkap dengan 5 perlakuan (P0, P1, P2, P3, P4) dan 4 ulangan. Total DOC ayam pedaging yang digunakan sebanyak 100 ekor dimasukkan ke dalam 20 kandang petak, setiap kandang petak diisi 5 ekor. Perlakuan dilakukan pada umur 15-35 hari (fase finisher). Perlakuan tingkat penggunaan campuran tepung bonggol pisang dan Indigofera sp. sebagai berikut:

P0: $50 \%$ Jagung $+40 \%$ Konsentrat $+10 \%$ Bekatul

P1: $50 \%$ Jagung $+40 \%$ Konsentrat $+7,5 \%$ Bekatul $+2,5 \%$ Campuran tepung bonggol pisang dan Indigofera sp.

P2: $50 \%$ Jagung $+40 \%$ Konsentrat $+5 \%$ Bekatul $+5 \%$ Campuran tepung bonggol pisang dan Indigofera sp.

P3: $50 \%$ Jagung $+40 \%$ Konsentrat $+2,5 \%$ Bekatul $+7,5 \%$ Campuran tepung bonggol pisang dan Indigofera sp.

P4: $50 \%$ Jagung $+40 \%$ Konsentrat $+10 \%$ Campuran tepung bonggol pisang dan tepung Indigofera sp.

\section{Variabel Pengamatan}

Variabel penelitian ini adalah mengamati performa ayam pedaging meliputi konsumsi pakan, pertambahan bobot badan, konversi pakan, indeks performa dan income over feed cost (IOFC). 
a. Konsumsi pakan

Konsumsi pakan merupakan total pakan yang dikonsumsi ternak dengan cara pemberian total dikurangi sisa dalam sehari

Konsumsi pakan (g/ekor) = Pakan yang diberikan $(\mathrm{g})$ - Pakan sisa $(\mathrm{g})$

b. Pertambahan Bobot badan

Pertambahan bobot badan (PBB) merupakan selisih antara bobot badan akhir dengan bobot badan awal.

$\mathrm{PBB}(\mathrm{g} /$ ekor $)=\mathrm{BB}_{\mathrm{t}}(\mathrm{g})-\mathrm{BB}_{\mathrm{t}-1}(\mathrm{~g})$

c. Konversi pakan / Feed Conversion Rate (FCR) Konversi pakan merupakan perbandingan antara konsumsi pakan dengan pertambahan bobot badan.

Konversi pakan $=\underline{\text { Konsumsi Pakan }}$

Pertambahan Bobot

d. Indeks performa

Indeks performa untuk mengetahui penampilan produksi yang terdiri dari bobot badan, konversi pakan, mortalitas, dan umur panen.

$\mathrm{IP}=(100-\%$ Mortalitas $) \times$ Rata-rata bobot

badan $(\mathrm{kg}) \times 100$

FCR $\times$ Umur panen

e. Income Over Feed Cost (IOFC)

IOFC merupakan perhitungan pendapatan kotor dalam satu usaha.

IOFC $=\{$ (Bobot badan $\times$ harga ayam hidup $)$

- konsumsi pakan $(\mathrm{kg}) \times$ harga pakan/kg) $\}$

\section{HASIL DAN PEMBAHASAN}

Berdasarkan hasil penelitian yang telah dilakukan, diperoleh hasil pengaruh dari pemberian tepung bonggol pisang dan Indigofera sp. sebagai pengganti bekatul dalam pakan terhadap performa ayam pedaging yang meliputi konsumsi pakan, pertambahan bobot badan, konversi pakan, indeks performa, dan Income Over Feed Cost (IOFC) yang disajikan pada Tabel 1.

Tabel 1. Pengaruh perlakuan terhadap performa ayam pedaging

\begin{tabular}{cccccc}
\hline Per & \multicolumn{5}{c}{ Variabel Pengamatan } \\
\cline { 2 - 6 } $\begin{array}{c}\text { laku } \\
\text { an }\end{array}$ & $\begin{array}{c}\text { Konsumsi Pakan } \\
\text { (g/ekor/35hari) }\end{array}$ & $\begin{array}{c}\text { PBB } \\
\text { (g/ekor/35hari) }\end{array}$ & $\begin{array}{c}\text { Konversi } \\
\text { Pakan }\end{array}$ & $\begin{array}{c}\text { Indeks } \\
\text { Performa }\end{array}$ & $\begin{array}{c}\text { IOFC } \\
\text { (Rp) }\end{array}$ \\
\hline P0 & $2376,08 \pm 37,96^{\mathrm{a}}$ & $1388,85 \pm 37,33^{\mathrm{a}}$ & $1,71 \pm 0,05$ & $284,16 \pm 15,04$ & $14478,04 \pm 658,30$ \\
P1 & $2410,28 \pm 30,89^{\mathrm{a}}$ & $1411,18 \pm 84,85^{\mathrm{a}}$ & $1,71 \pm 0,08$ & $289,58 \pm 31,94$ & $14692,30 \pm 1411,20$ \\
P2 & $2473,51 \pm 78,16^{\mathrm{b}}$ & $1476,44 \pm 85,81^{\mathrm{b}}$ & $1,68 \pm 0,05$ & $308,52 \pm 26,85$ & $15511,85 \pm 1229,35$ \\
P3 & $2542,30 \pm 12,58^{\mathrm{c}}$ & $1503,15 \pm 58,28^{\mathrm{b}}$ & $1,69 \pm 0,07$ & $311,36 \pm 25,03$ & $15718,45 \pm 1096,76$ \\
P4 & $2580,35 \pm 76,45^{\mathrm{c}}$ & $1543,64 \pm 81,60^{\mathrm{b}}$ & $1,67 \pm 0,04$ & $323,04 \pm 24,87$ & $16204,86 \pm 1147,38$ \\
\hline
\end{tabular}

Keterangan: Superskrip yang berbeda pada kolom yang sama menunjukkan perbedaan yang nyata $(\mathrm{P}<0,05)$ dan sangat nyata $(\mathrm{P}<0,01)$

\section{Perlakuan terhadap Konsumsi Pakan}

Hasil penelitian yang telah dianalisis statistika menunjukkan bahwa penggunaan campuran tepung bonggol pisang dan Indigofera sp. sebagai pengganti bekatul selama penelitian berpengaruh sangat nyata $(\mathrm{P}<0,01)$ terhadap konsumsi pakan. Konsumsi pakan yang dihasilkan setiap perlakuan dari yang terendah hingga tertinggi yakni P0 $(2376,08 \pm 37,96), \quad$ P1 $(2410,28 \pm 30,89)$, P2 $(2473,51 \pm 78,16), P 3$ $(2542,30 \pm 12,58), \quad$ P4 $\quad(2580,35 \pm 76,45)$ g/ekor/35 hari. Hasil Uji Jarak Berganda Duncan (UJBD) menunjukkan penggunaan campuran tepung bonggol pisang dan Indigofera sp. sebanyak 7,5\% (P3) dan 10\% (P4) mampu menggantikan bekatul pada setiap tingkatannya. Nilai konsumsi pakan diperoleh dari data selam 35 hari (waktu penelitian) dengan menghitung total pemberian pakan yang diberikan dikurangi sisa pakan maupun pakan yang tercecer dalam satu hari, yang dinyatakan dalam g/ekor/hari. 
Peningkatan konsumsi pakan selama penelitian diduga adanya perbedaan persentase kandungan energi metabolisme dan protein pada pakan pada setiap perlakuan. Rataan kandungan energi metabolisme P0-P4 yakni $2973 \mathrm{kkal} / \mathrm{kg}$, sedangkan rataan kandungan protein kasar P0-P4 yakni 22,09\%. Hal ini sesuai dengan pendapat Silondae dan Polakitan (2018) yakni untuk ayam pedaging fase finisher besaran rasio energi metabolisme dan protein kasar sebesar $3000 \mathrm{kkal} / \mathrm{kg}$ dan protein $22 \%$.

Imbangan energi metabolisme dan protein merupakan pembatas konsumsi pakan pada ternak unggas, karena ternak akan berhenti makan apabila kebutuhan energi terpenuhi, sehingga maksud dari imbangan energi dan protein untuk mencukupi kebutuhan minimum protein karena kurangnya energi dalam pakan akan merubah protein di tubuh ternak menjadi energi (Allama, Sjofjan, Widodo dan Prayogi, 2012). Berdasarkan kandungan nutrisi, emakin tinggi tingkat penggunaan campuran tepung bonggol pisang dan Indigofera sp. maka semakin rendah kandungan energi metabolisme dalam pakan. Ditinjau dari hasil konsumsi pakan P0-P4, energi metabolisme berbanding terbalik dengan konsumsi pakan. Hal ini sesuai dengan pendapat Fitro, dkk.(2015), yakni tingkat energi dalam pakan menunjukkan banyaknya pakan yang dikonsumsi ayam. Jumlah pakan yang dikonsumsi berbanding terbalik dengan kandungan energi dalam pakan. Menurut Anggitasari, dkk.(2016), menyetakan bahwa pembatas ayam berhenti makan adalah ketercukupan energi, karena tingkah laku ayam menunjukkan bahwa ayam akan makan apabila energi yang ada kurang, namun ayam akan berhenti makan apabila energi sudah terpenuhi atau cukup.

\section{Perlakuan terhadap Pertambahan Bobot Badan}

Hasil analisis statistika didapatkan penggunaan campuran tepung bonggol pisang dan Indigofera sp. sebagai pengganti bekatul selama penelitian berpengaruh berbeda nyata $(\mathrm{P}<0,05) \quad$ terhadap pertambahan bobot badan. Pertambahan bobot badan yang didapatkan pada setiap perlakuan selama penelitian dari terendah hingga tertinggi yaitu P0 $(1388,85 \pm 37,33)$, P1 $(1411,18 \pm 84,85)$, P2 $(1476,44 \pm 85,81)$, P3 $(1503,15 \pm 58,28)$, P4 $(1543,64 \pm 81,60)$ g/ekor/35 hari. Hasil Uji Jarak Berganda Duncan (UJBD) menunjukkan penggunaan campuran tepung bonggol pisang dan Indigofera sp. sebanyak 7,5\% (P3) dan $10 \%$ (P4) mampu menggantikan bekatul untuk meningkatkan pertambahan bobot badan ayam pedaging.

Peningkatan pertambahan bobot badan dipengaruhi oleh jenis pakan yang diberikan pada ayam pedaging. Kandungan energi metabolisme dan protein pada pakan sangat berpengaruh terhadap pertambahan bobot badan. Hal ini sesuai dengan pendapat Allama, dkk.(2012), yang menyatakan bahwa kandungan protein dan energi dalam pakan menentukan pertambahan bobot badan, sehingga keseimbangan pakan tentang kandungan energi dan protein perlu diperhatikan karena memiliki pengaruh yang nyata terhadap PBB. Pemberian tepung boonggol pisang berkontribusi besar terhadap kandungan energi pada pakan yakni sebesar 2517,20 kkal/kg. Menurut Saragih (2013), jenis karbohidrat yang terkandung pada tepung bonggol pisang adalah karbohidrat mudah tercerna (pati) . Pati terdiri dari amilosa dan amilopektin dalam ikatan polimer glukosa.

Kandungan pati pada bonggol pisang sebesar $76 \%$ dan jenis pati bonggol pisang menyerupai pati tepung sagu dan tapioca. Karbohidrat yang ada dalam bongkol pisang merupakan karbohidrat yang mudah dicerna oleh unggas sehingga dapat meningkatkan konsumsi pakan. Pemberian tepung Indigofera sp. berkontribusi besar terhadap kandungan protein pada pakan yakni sebesar 33,15\%. Menurut Zulfanita, dkk.(2011), fungsi dari protein yaitu dapat membentuk jaringan dan memperbaiki jaringan tubuh yang rusak, untuk kebutuhan berproduksi karena dapat diubah menjadi energi. 


\section{Perlakuan terhadap Konversi Pakan}

Hasil analisis statistika didapatkan penggunaan campuran tepung bonggol pisang dan Indigofera sp. sebagai pengganti bekatul selama penelitian memberikan pengaruh tidak berbeda nyata $(\mathrm{P}>0,05)$ terhadap konversi pakan. Niai rataan konversi pakan semua perlakuan (P0-P4) ayam pedaging sebesar 1,69. Hal ini tidak sesuai dengan pendapat Silondae dan Polakitan (2018), bahwa konversi pakan pada ayam pedaging selama 5 minggu pada kandang litter sebesar 1,6. Konversi pakan yang lebih tinggi tersebut dapat disebabkan adanya peningkatan yang dihasilkan tidak sebanding dengan peningkatan konsumsi pakan.

Konversi pakan sangat erat kaitannya dengan penggunaan pakan yang diberikan. Pakan perlakuan P0-P4 yang diberikan berupa bentuk pellet. Pemberian dalam bentuk pellet dapat meminimalisir pakan yang terbuang sehingga pemberian pakan dapat dikatakan efisien dan dapat menghasilkan konversi pakan yang rendah. Hal ini sesuai dengan Anggitasari, dkk.(2016) yang menyatakan bahwa bentuk pakan mempengaruhi konversi pakan, bentuk pakan terbaik untuk unggas adalah crumble dan pellet karena bentuk pakan crumble mampu mengurrangi jumlah pakan yang hilang di dalam litter.Binowo, Tulung, Londok dan Regar (2019), menambahkan bahwa tolak ukur untuk memberikan penilaian efisiensi pakan menggunakan konversi pakan. jika nilai konversi pakan rendah maka efisiensi penggunaan pakan baik, begitupun sebaliknya.

\section{Perlakuan terhadap Indeks Performa}

Hasil analisis statistika didapatkan penggunaan campuran tepung bonggol pisang dan Indigofera sp. sebagai pengganti bekatul selama penelitian memberikan pengaruh tidak berbeda nyata $(\mathrm{P}>0,05)$ terhadap indeks performa. Berdasarkan Tabel 1, niai rataan indeks performa semua perlakuan ( $\mathrm{P} 0-\mathrm{P} 4)$ ayam pedaging selama penelitian yakni 303. Nilai tersebut termasuk kategori sangat baik. Hal ini selaras dengan pendapat Sujana, dkk.(2011), bahwa nilai indeks performa di atas 301 termasuk kategori sangat baik. Hal ini diperkuat dengan pendapat Medion (2010) menyatakan standar IP yang baik adalah di atas 300, dan semakin tinggi nilai indeks performa maka semakin berhasil peternakan ayam pedaging tersebut. Meskipun dari keempat perlakuan tidak berbeda nyata akan tetapi perlakuan P4 tergolong kategori sangat baik, karena didukung oleh faktor pertambahan bobot badan yang dihasilkan mencapai 1543,64 gram/ekor/35 hari dengan nilai konversi 1,67.

Banyak faktor yang dapat mempengaruhi indeks performa pada ayam pedaging. Faktor yang dapat mempengaruhi nilai indeks performa adalah rata-rata bobot badan ayam saat panen, persentase kematian, rataan umur panen, dan konversi pakan. Faktor yang perlu diperhatikan adalah persentase kematian ternak atau mortalitas. Mortalitas merupakan salah satu petunjuk menilai keberhasilan suatu usaha peternakan. Angka kematian (mortalitas) selama penelitian sebesar 5\%. Hal ini tidak sesuai dengan pendapat Allama, dkk.(2012) menyatakan angka mortalitas yang baik harus kurang atau sama dengan $5 \%$ bagi ayam pedaging.

\section{Perlakuan terhadap Income Over Feed Cost (IOFC)}

Hasil analisis statistika didapatkan penggunaan campuran tepung bonggol pisang dan Indigofera sp. sebagai pengganti bekatul selama penelitian tidak memberikan pengaruh yang nyata $(\mathrm{P}>0,05)$ terhadap IOFC (Tabel 1). Kisaran IOFC selama penelitian dari semua perlakuan $\mathrm{P} 0-\mathrm{P} 4$ adalah Rp14478,04,- sampai Rp16204,86,dengan rata-rata Rp15321,10,-/ekor. Perlakuan pakan kontrol memiliki nilai IOFC terendah, hal ini disebabkan karena jumlah konsumsi pakan tidak sebanding dengan PBB yang dihasilkan ternak sehingga nilai konversi pakan tinggi menyebabkan nilai IOFC rendah. Menurut Allama, dkk.(2012), faktor yang mempengaruhi nilai IOFC adalah 
pendapatan dan biaya pakan yang dikeluarkan selama penelitian. Harga pakan pada semua perlakuan cenderung meningkat dari P0-P4 yaitu P0 (Rp4428,-/kg), P1 (Rp4443,-/kg), P2 (Rp4458,-/kg), P3 (Rp4473,-/kg), P4 (Rp4488,-/kg). Perbedaan harga pakan dari setiap perlakuan disebabkan karena mahalnya harga campuran tepung bonggol pisang dan Indigofera sp. yakni ( \pm Rp.50,-/kg). Sehingga dengan bertambahnya penggunaan campuran tepung bonggol pisang dan Indigofera sp. maka semakin tinggi biaya pakan per $\mathrm{kg}$. Walaupun biaya pakan $\mathrm{P} 0$ lebih rendah $\mathrm{Rp} 4438,-/ \mathrm{kg}$ tetapi menghasilkan PBB yang lebih rendah sehingga menghasilkan IOFC yang lebih rendah. Sebaliknya, walaupun biaya pakan P4 lebih tinggi (Rp4488,-) akan tetapi menghasilkan PBB yang lebih tinggi sehingga menghasilkan IOFC yang lebih tinggi pula. Hal ini sesuai dengan pendapat Fitro, dkk.(2015) yang menyatakan tingginya nilai IOFC ini dipengaruhi oleh efisiensi ayam dalam mengkonversikan pakan menjadi daging, jika nilai konversi pakan menjadi daging baik maka nilai IOFC akan tinggi, begitupun sebaliknya apabila nilai konversi pakan menjadi daging rendah makan nilai IOFC akan rendah.

\section{KESIMPULAN DAN SARAN}

\section{Kesimpulan}

Penggunaan campuran tepung bonggol pisang dan Indigofera sp. sebagai pengganti bekatul dari hasil penelitian menunjukkan adanya peningkatan konsumsi pakan, PBB, indeks performans dan IOFC serta dapat menurunkan konversi pakan. Perlakuan terbaik adalah penggunaan campuran tepung bonggol pisang dan Indigofera sp. sebagai pengganti bekatul sebesar $10 \%$.

\section{Saran}

Penelitian lebih lanjut dengan penggunaan campuran tepung bonggol pisang dan Indigofera sp. sebagai pengganti bekatul diatas $10 \%$

\section{DAFTAR PUSTAKA}

Allama, H., Sjofjan, O., Widodo, E., \& Prayogi, H. S. (2012). Pengaruh penggunaan tepung ulat kandang (Alphitobius diaperinus) dalam pakan terhadap penampilan produksi ayam pedaging. Jurnal Ilmu-Ilmu Peternakan, 22(3), 1-8.

Aswandi. (2016). Performa ayam ras pedaging yang mendapat pakan komersil mengandung tepung bonggol pisang. JITP, 4(3), 98-103.

Binowo, S., Tulung, B., Londok, J. J. M. R., \& Regar, M. N. (2019). Efek pembatasan pakan dan sumber serat kasar berbeda terhadap performa ayam pedaging. ZOOTEC, 39(1), 112-121. https://doi.org/10.35792/zot.39.1.2019.23808

Damayanthi, E., \& Listyorini, D. I. (2007). Pemanfaatan tepung bekatul rendah lemak pada pembuatan kripik simulasi. Jurnal Gizi Dan Pangan, $1(2)$, 34-44. https://doi.org/10.25182/jgp.2006.1.2.34-44

Fitro, R., sudrajat, D., \& Dihansih, E. (2017). Performa ayam pedaging yang diberi ransum komersial mengandung tepung ampas kurma sebagai pengganti jagung. Jurnal Peternakan Nusantara, $\quad 1(1), \quad 1-8$. https://doi.org/10.30997/jpnu.v1i1.131

Medion. (2010). Berhasil atau Tidakkah Pemeliharaan Broiler Anda.

Nuningtyas, Y. (2014). Pengaruh penambahan tepung bawang putih (allium sativum) sebagai aditif terhadap penampilan produksi ayam pedaging. TERNAK TROPIKA Journal of Tropical Animal Production. TERNAK TROPIKA Journal of Tropical Animal Production, 15(1), 21-30. 
Santi, M. A. (2018). Penggunaan tepung pucuk indigofera zollingeriana sebagai pengganti bungkil kedelai dalam ransum dan pengaruhnya terhadap kesehatan ayam broiler. Jurnal Peternakan (Jurnal of Animal Science), 1(2), 17-22.

Saragih, B. (2013). Analisis mutu tepung bonggol pisang dari berbagai varietas dan umur panen yang berbeda. Jurnal TIBBS, 9(1), 22-29.

Silondae, H., Polakitan, D., \& Polakitan, D. (2018). Pengaruh imbangan energi dan protein serta kepadatan kandang terhadap penampilan ayam pedaging. Jurnal Peternakan Indonesia (Indonesian Journal of Animal Science), 20(3), 175-180. https://doi.org/10.25077/jpi.20.3.175180.2018
Sitompul, S. A., Sjofjan, O., \& Djunaidi, I. H. (2016). Pengaruh beberapa jenis pakan komersial terhadap kinerja produksi kuantitatif dan kualitatif ayam pedaging. Buletin Peternakan, 40(3), 187-196. https://doi.org/10.21059/buletinpetern ak.v40i3.11622

Supartini, N., \& Fitasari, E. (2011). Penggunaan bekatul fermentasi "Aspergillus Niger " dalam pakan terhadap karakteristik organ dalam ayam pedaging. Buana Sains, 11(2), 127-136.

https://doi.org/10.33366/BS.V11I2.164

Zulfanita, Roisu, E., \& Utami, D. P. (2011). Pembatasan ransum berpengaruh terhadap pertambahan bobot badan ayam broiler pada periode pertumbuhan. MEDIAGRO, 7(1), 59-67. 